\title{
The Federal Constitutional Court's Emergency Power to Intervene: Provisional Measures Pursuant to Article 32 of the Federal Constitutional Court Act
}

\author{
By Andreas Maurer \\ Suggested Citation: Andreas Maurer, The Federal Constitutional Court's Emergency Power to Intervene: \\ Provisional Measures Pursuant to Article 32 of the Federal Constitutional Court Act, 2 German Law Journal (2001), \\ available at http://www.germanlawjournal.com/index.php?pageID=11\&artID=70 \\ [1] In three high-profile cases the Bundesverfassungsgericht (BVerfG -- Federal Constitutional Court) was recently \\ called upon to exercise its authority to issue a temporary injunction in proccedings referred to as einstweilige \\ Anordnungen (provisional measures). Article 32(1) of the Bundesverfassungsgerichtgesetz (BVerfGG - Federal \\ Constitutional Court Act) provides:
}

In a dispute the Federal Consitutional Court may deal with a matter provisionally by means of a temporary injunction if this is urgently needed to avert serious detriment, ward off imminent force or for any other important reason for the common

good.

[2] This report provides a general introduction to the Court's power to issue a temporary injunction pursuant to Article 32 of the BVerfGG, as a way of providing a context for reports in this issue of the German Law Journal concerning: (a) the Court's denial of a requested injunction in the Lifetime Partnership Act Case on July 18, 2001 (reported below under Public Sector); (b) the Court's grant of a requested injunction in the NPD Party-Ban Case on July 3 , 2001 (reported below under Public Sector); and (c) the Court's denial of a requested injunctions in the Love Parade I Fuck Parade Cases on July 12, 2001 (reported below under Legal Culture).

[3] A temporary injunction issued prusuant to Article 32 BVerfGG provides preliminary legal protection. It is not part of the substantive proceeding but an autonomous procedure. (1) A temporary injunction can be initiated by the Court itself or by any party to the substantive proceedings. A request for a temporary injunction must, however, be bound to a case potentially or actually under review by the Court as a substantive matter. (2) In this respect, the main purpose of the provisional measures is to protect the Court's jurisdiction from being mooted by empowering the Court to prevent an alleged constitutional harm from taking place before the Court has had the opportunity to determine (in the substantive proceedings before it) whether a constitutional harm will actually result. As the constitution primarily concerns itself with limiting the powers of the State, the potential constitutional violators at the center of substantive proceedings before the Court (and therefore, at the center of a requested temporary injunction) are almost exclusively state actors like the legislature, the executive and the ordinary courts. (3) For this reason, Article 32 provisional measures play an important role in maintaining the checks and balances that are inherent to the separation of powers in the German democracy, by ensuring that the judiciary (the Constitutional Court in this instance) has the opportunity to exercise its jurisdiction to review the acts of the other branches of government at a point in time when such review is most relevant and will be most effective. (4) One comentator has described this protective function of Article 32 in the

following

way:

A temporary injunction exists in the case that, without the granting of such an injunction, there is the literal danger that the proceedings in the substantive case, in consideration of the facts, will become senseless or even absurd. (5)

[4] The Court has established, in spite of the important role Article 32 can play in maintaining a meaningful separation of powers, that granting such temporary injunctions will remain the exception, reserved for those cases in which the grounds for the application are so severe as to make the Court's intervention inevitable, that is to say, when an application for an injunction is justified by "especially important grounds."

[5] The first level of the Court's austere review of requests for a temporary injunction is the strict application of the controlling procedural requirments. (7) It is, for example, essential, that the Court have jurisdiciton over the underlying, substantive case and that the requested temporary injunction touches upon the matter in dispute in the underlying proceedings. (8) The Court has, however, liberally interpreted the terms of Article 32 . The required "serious detriment" or "imminent force" refers only to a "severe disadvantage." (9) The Court has also softened the "public good" requirement so as to extend the range of Article 32 to include cases, the impact of which is seemingly limited to a specific individual. The Court first made this shift in a case concerning the imposition of a criminal sentence, explaining that the broader public's trust in the administration of justice could be at issue in a specific criminal case.

[6] The following are some of the factors the Court takes into consideration when deciding on a requested temporary injunction. A requested injunction is more likely to meet with success if the number of those to be affected by the alleged constitutional violation is large, even if the matter is being raised in the context of a specific individual's case (by establishing a rule controlling the deportation of foreigners or the admission to practice of attorneys, for example). 
(11) Fundamental to the Court's consideration of a requested injunction is the political nature of the issue. The Court employs a degree of judicial self-restraint in cases involving law-making or the implementation of the law by executive agencies in order that the provisional measures do not become a tool for the parliamentary opposition to thwart the democratic process. In such cases (as with the injunction requested and denied in the Lifetime Partnership Act Case, reported below under Public Sector) the Court applies "an especially strict standard of review," (12) as it considers whether the disadvantages of delaying the entry into force of the law outweigh the disadvantages of allowing a law to enter into force only to have that law later striken as unconstitutional in the underlying, substantive proceedings. (13) Considerations regarding the merits of the underlying, substantive proceedings should not play a role, (14) but the Court often appears to take into consideration the likelihood of success of the underlying, substantive case. In this sense, the Court may base its decision regarding the grant or denial of an injunction on the procedural shortcomings of the underlying case, including its obvious inadmissability or that it is obviously unfounded. (15) The Court may also weigh the success of the underlying case on its merits, in spite of the general legal principle that sharply divides strictly procedural matters (like a request for a temporary injunction) from the merits of a case. Perhaps the best evidence of this anticipation of the merits is the near exact consistency in the Court's decision on requested injunctions and the following decision on the merits of the underlying case.

(16)

\section{For}

More

Information

Bundesverfassungsgerichtsgesetz (BVerfGG - Federal Constitutional Court Act) on line (in English) at the German Law Archive:

http://www.iuscomp.org/gla

(1) Those proceedings that are permissible to the FCC are enumerated in $\S 13$ Bundesverfassungsgerichtsgesetz (Federal Constitutional Court Act). The most common proceedings are: Verfassungsbeschwerde (constitutional complaint - 126,962 proceedings until 2000), Normenkontrollverfahren (judicial proceedings on the constitutionality of laws - 3,288 proceedings until 2000) and Einstweilige Anordnungen (temporary injunctions - 1,157 proceedings until 2000).

(3) Jörg Berkemann, Einstweilige Anordnung (oldarticle 32) (Umbach/Clemens, eds., Bundesverfassungsgerichtsgesetz $\quad$ Kommentar $\quad$ (1992)) p. $\quad 571$. (2) Lechner/Zuck, Bundesverfassungsgerichtsgesetz, 4 th $\quad$ ed., $1996, \quad \S \quad 32$ no. 4. (4) Id. Id. $\quad$ at at $571-572$.

(5) Id. at 572. „Eine eAnO setzt voraus, dass ohne ihren Erlass die ernsthafte Gefahr besteht, dass das Verfahren der Hauptsache angesichts vollendeter Tatsachen sinnlos, ja sinnwidrig wird." $\begin{array}{lllllll}\text { (6) Id. } & \text { at } & 594 & \text { (citing } & \text { BVerfGE } & 33, & 232\end{array}$ (7) The Court grants only about $20 \%$ of requested provisional measures. Id. at 570 . (8) Id.

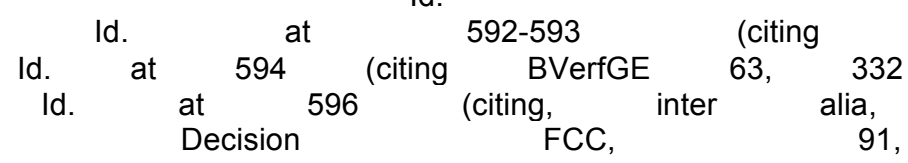
at at 592. Id. and this violation would cause very grave damages. In fact, aspects of constitutionality are most probably regularly taken into consideration, even if the FCC denies that (see: Berkemann, Das verdeckte summarische Verfahren des Bundesverfassungsgerichts, $\quad$ JURISTENZEITUNG $\quad 1993, \quad$ p. $\quad 161 \quad$ seq.). (15) Pursuant to Articles 93a and 93c of the Federal Constitutional Court Act, the Court may summarily dismiss a constitutional complaint, if it lacks "constitutional significance" or if "the issue determining the judgement of the complaint has already been decided upon by the Federal Constitutional Court, . . "Regarding the role of these rules in Article 32 proceedings, see Robbers, JURISTISCHE SCHULUNG 1994, p. 1031, 1032; Decision FCC, 1 BvQ $23 / 01$ 18

(16) Jörg Berkemann, Einstweilige Anordnung (oldarticle Bundesverfassungsgerichtsgesetz Kommentar (1992)) pp. 571 and 601-602. uly

2001. 